\title{
Autogeny as successful reproductive strategy in high altitude black- flies (Diptera, Simuliidae)
}

\author{
J.E. Raastad' \\ J.O. Solem ${ }^{2}$
}

Keywords : Diptera, Simuliidae, mountain, Norway, autogeny.

The black -fly fauna of Drovrefjell National Park, Central Norway, was investigated at elevations between $870 \mathrm{~m}$ and $1630 \mathrm{~m}$ and covered the sub-alpine, low- and middle-alpine vegetation zones. We found 13 black-fly species and a dominance of three non-bloodsucking species, Prosimulium ursinum, Cnephia tredecimata and Eusimulium crassum, in this area. E. crassum dominated the bog stream habitat, while $C$. tredecimata and $P$. ursinum dominated the outlet habitat. The parthenogenesis of $\boldsymbol{P}$. ursinum is an advantage over a sexual reproduction in the extreme habitat of glacier fed outlets. While mammalophilic species were absent or scarce, we found a high proportion of bird-feeding Eusimulium spp. $E$. corniferum and $E$. carpathicum have not been previously recorded from Norway.

L'autogénie, une stratégie reproductive réussie chez les simulies (Diptera, Simuliidae) de haute altitude.

Mots clés : Diptera, Simuliidae, montagne, Norvège, autogénie.

La faune des simulies du Parc national de Dovre, situé au centre de la Norvège, a été étudiée de $870 \mathrm{~m}$ à $1630 \mathrm{~m}$ d'altitude, recoupant les zones de végétations sub-alpine, moyenne et basse. Treize espèces de simulies ont été identifiées avec la prédominance de trois espèces non-hématophages : Prasimulium ursinum, Cnephia tredecimata et Eusimulium crassum. E. crassum domine dans l'habitat marécageux du cours d'eau, alors que $C$. tredecimata et $P$. ursinum dominent à l'embouchure. La parthénogénèse chez $P$. ursinum constitue un avantage sur la reproduction sexuée dans l'habitat aux conditions extrêmes situé à l'embouchure des cours d'eau alimentés par les glaciers. Alors que les espèces mammalophiles étaient rares ou absentes, plusieurs espèces avicoles d'Eusimulium ont été observées. E. corniferum et $E$. carpathicum sont signalées en Norvège pour la première fois.

\section{Introduction}

Black-flies are of particular interest at high altitudes and latitudes as they exhibit adaptations to severe climate (Downes 1962, 1964, 1965).

This paper focuses on one such adaptation, autogeny, i.e. the capability to produce ripe eggs without blood-feeding. Dovrefjell National Park proved to be an interesting study locality in this context.

Dovrefjell National Park has been established mainly because of its spectacular scenery and topography, rich vegetation and variety of bird species. The invertebrate fauna has been much neglected. However, during the last decade there has been

1. University of Oslo, Zoological Muscum, Sarsgt. 1, N-0562 Oslo 5, Norway.

2. University of Trondheim, The Museum, N-7004 Trondheim, Norway. intensive insect sampling within the park, and several papers have been published dealing with the distribution of species and composition of insect communities, e.g. Ephemeroptera (Nøst 1985), Trichoptera (Solem 1985 a, b), Collembola (Fjellberg 1987), Plecoptera (Solem et al. 1987), Thysanoptera (Olsen 1987), Neuroptera-Mecoptera (Greve et $a l .1987$ a) and some families of Diptera (Hofsvang et al. 1987, Mendl et al. 1987, Greve et al. 1987 b).

National parks in Norway are protected against major disturbances and they should be excellent reference areas for life sciences, but documentation of the fauna is a necessary requisite before a territory can be considered a reference area. In a zoogeographic context we have a particular responsibility for the NNW European fauna. This also applies to taxonomy and systematics on a broad scale. The fauna inhabiting the Norwegian high mountain areas is of great interest in this respect. 


\section{Study area}

The Dovrefjell mountains belong to the western part of the Scandinavian Caledonians. Kongsvoll biological station $\left(62^{\circ} 17^{\prime} \mathrm{N}, 09^{\circ} 59^{\prime} \mathrm{E}\right)$ is situated close to the river Driva (fig. 1), which is the main water course in the area and separates the valley in two geological regions. The eastern part is mainly medium grade mica schist and green-stone of cambro-silurian age. The western part is mainly a basal gneiss built up of high-grade gneisses and schist of precambrian age.

The study area lies entirely above the coniferous tree line, and is characterised by the birch forest belt which has an upper limit of $1080 \mathrm{~m}$. The lowest sampling sites were at about $900 \mathrm{~m}$ and the highest was at $1630 \mathrm{~m}$. Following the definitions of Sjørs (1967) and Rønning (1972), the sampling site are distributed in the sub-alpine zone (up to $1080 \mathrm{~m}$ ) and in the low- (1080-1 $400 \mathrm{~m})$ and middle-alpine (1 400-1 $630 \mathrm{~m}$ ) vegetation zones.

The climate of the area is mainly continental, with a yearly precipitation of $470 \mathrm{~mm}$ at Kongsvoll. At Hjerkin $(959 \mathrm{~m}), 10 \mathrm{~km}$ south of Kongsvoll, the annual mean temperature is $-0.1^{\circ} \mathrm{C}$. On average only 19 days a year have temperature above $10^{\circ} \mathrm{C}$ (Nordhagen 1943). The ice and snowfree period is normally from late May to early October. The streams are cold for much of the summer, and reaches on average a maximum temperature of $10^{\circ} \mathrm{C}$ for a short periode at the end of July.

\section{Material and methods}

The material was sampled from 14 sites in the surroundings of Kongsvoll (fig. 1). We collected larvae and pupae at 13 sites. Adult flies were obtained from reared pupae. At two sites adult flies were sampled using Malaise traps.

The Malaise traps were emptied once a week in the summer period from May to September. Both traps gave series of samples, representing one lowand one middle-alpine outlet habitat : Stropla, the outlet of Stroplsjøen at $1289 \mathrm{~m} \mathrm{(fig.} \mathrm{1,} \mathrm{site} \mathrm{9)} \mathrm{was}$ sampled throughout the summer of 1982 , and Kallvella, the outlet of Gluptjern at $1452 \mathrm{~m}$ (fig. 1, site 10) was sampled throughout the summer of 1983.

In August 1986 larvae and pupae were sampled from 8 streams. Driva (site 1 ) is a torrential, medium sized sub-alpine river at $870 \mathrm{~m}$. Sites $2-5$ are small bog streams of $20-60 \mathrm{~cm}$ width with much humus in a marshy area in the sub-alpine birch forest at $1040-1080 \mathrm{~m}$. Site 6 is a sandy low-alpine stream of $80-100 \mathrm{~cm}$ width at $1160 \mathrm{~m}$ and with only a low humus content. Site 7 is Kallvella, site 8 Stropla, both small torrential rivers at $1160 \mathrm{~m}$ in the lowalpine zone. In June to August 1988 further samples of larvae and pupae were obtained from the outlet of Gluptjern (site 10). In addition samples were collected from the outlet of Istjern (site 11, $1630 \mathrm{~m}$ ), which is just below the glacier Snøhetta, the stream Jerosbekken (site $12,930 \mathrm{~m}$ ) in the subalpine zone, and the streams Blesbekken (site 13) and Raubekken (site 14) both at $1200 \mathrm{~m}$ in the lowalpine zone. The small lakes Istjern and Gluptjern are both glacier fed.

Altogether 530 larves and pupae were collected and identified. Adults from the Malaise traps were in such huge numbers that only subsamples were identified and counted. Adult black-flies were also reared from mature pupae in the laboratory following the techniques of Wood \& Davies (1966). The nomenclature follows the classification of Raastad (1979).

\section{Results}

\subsection{Malaise trap samples}

The Malaise traps did not capture black-flies until the end of July and onwards (Table I-II) even though the traps were set up much earlier. At Stropla we identified three species, Prosimulium ursinum (Edwards), Cnephia tredecimata (Edwards) and Simulium noelleri Friederichs (Table I). The flight period of $C$. tredecimata was from late July and extended through August in 1982. C. tredecimata was present in large numbers, and it totally outnumbered the other two species. The males of $C$. tredecimata were far more numerous than the females in the samples, although the females increased in numbers on August 14 and 21. Dissection revealed that the females had ripe eggs but empty and non-functional guts. The parthenogenetic and triploid $P$. ursinum was represented only by three females at Stropla in late July and mid August, and S. noelleri by a single male in late August.

At Gluptjern only C. tredecimata was present, but again in large numbers (Table II). In contrast to Stropla, the females outnumbered the males at Gluptjern and again all females were gravid. The 


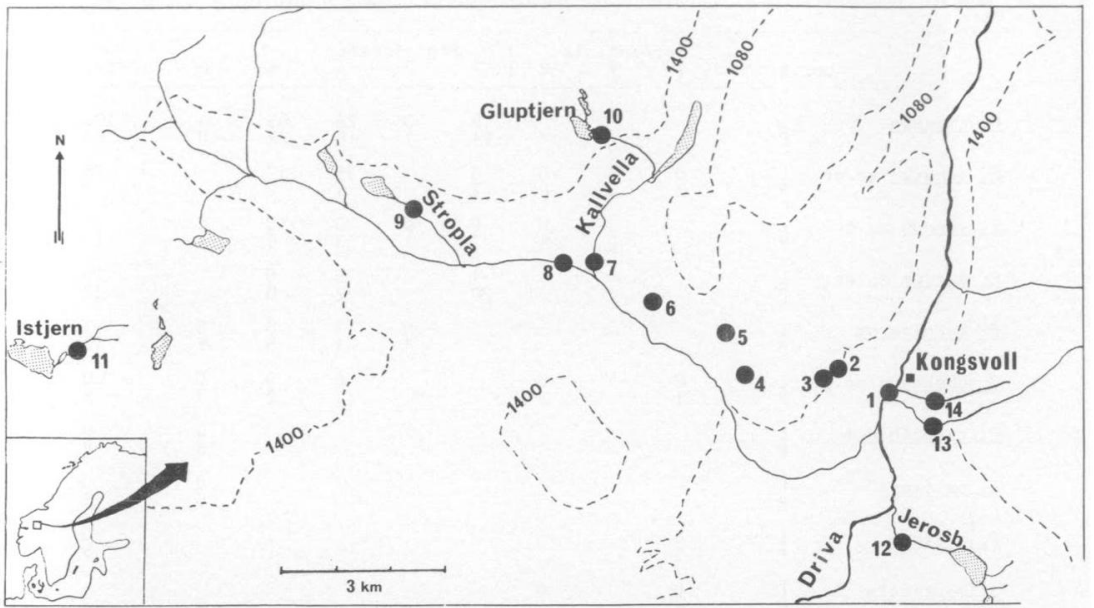

Fig. 1. Map of the study area showing collecting sites related to altitude contour lines.

Table I. Numbers of adult black-flies (females and males) from Malaise trap catches at Stropla outlel in July-August 1982.

\begin{tabular}{|c|c|c|c|c|c|c|c|c|}
\hline Date: & & 15.7 & 29.7. & 6.8. & 14.8 & 21.8 & 28.8. & Total \\
\hline P. ursinum & $F$ & 0 & 1 & 0 & 1 & 1 & 0 & 3 \\
\hline C. tredecimata & F & $\begin{array}{l}0 \\
0\end{array}$ & $\begin{array}{r}3 \\
20\end{array}$ & 80 & $\begin{array}{l}16 \\
74\end{array}$ & $\begin{array}{l}23 \\
79\end{array}$ & $\begin{array}{r}6 \\
40\end{array}$ & 290 \\
\hline S. noelleri & F & $\begin{array}{l}0 \\
0\end{array}$ & $\begin{array}{l}0 \\
0\end{array}$ & $\begin{array}{l}0 \\
0\end{array}$ & $\begin{array}{l}0 \\
0\end{array}$ & $\begin{array}{l}0 \\
0\end{array}$ & $\stackrel{0}{1}$ & 1 \\
\hline
\end{tabular}

Table II. Numbers of adult black-flies (females and males) from Malaise trap catches at Gluptjern outlet in August-September 1983.

\begin{tabular}{|c|c|c|c|c|c|c|}
\hline & & 10.8 . & 28.8 . & 4.9. & 10.9 & Total \\
\hline C. trederimata & F & $\begin{array}{r}42 \\
6\end{array}$ & 62 & $\begin{array}{r}80 \\
5\end{array}$ & $\begin{array}{r}55 \\
5\end{array}$ & 60 \\
\hline
\end{tabular}


Table III. Numbers of black-fly larvae and pupae collected from eight streams at Dovrefjell in August 1986.

\begin{tabular}{|c|c|c|c|c|c|c|c|c|c|c|}
\hline \multicolumn{2}{|c|}{ Lac.\#: } & \multicolumn{3}{|c|}{${ }_{1}^{T}{ }_{7} 8$} & \multicolumn{3}{|c|}{$2_{3}^{\text {Bng streams }}$} & 5 & 6 & Total \\
\hline E. r rassum & $\stackrel{\mathrm{L}}{\mathrm{P}}$ & & & & $\begin{array}{r}2 \\
44\end{array}$ & 3 & $\begin{array}{l}26 \\
16\end{array}$ & $\begin{array}{l}69 \\
22\end{array}$ & $\begin{array}{l}1 \\
0\end{array}$ & $\begin{array}{r}101 \\
83\end{array}$ \\
\hline S. ornatum sp.gr. & $\stackrel{L}{P}$ & $\frac{0}{2}$ & 5 & 20 & $\begin{array}{l}0 \\
2\end{array}$ & & $\begin{array}{r}39 \\
1\end{array}$ & $\begin{array}{r}12 \\
0\end{array}$ & & 78 \\
\hline E. vernum sp.gr. & $\stackrel{\mathrm{L}}{\mathrm{P}}$ & & $\begin{array}{l}1 \\
0\end{array}$ & $\begin{array}{l}6 \\
4\end{array}$ & $\stackrel{0}{1}$ & $\begin{array}{l}0 \\
1\end{array}$ & $\begin{array}{l}0 \\
3\end{array}$ & $\begin{array}{r}19 \\
0\end{array}$ & $\begin{array}{l}5 \\
4\end{array}$ & $\begin{array}{l}31 \\
13\end{array}$ \\
\hline E. aureum sp.gr. & $\stackrel{L}{\mathrm{~L}}$ & & & & 20 & & $\frac{9}{2}$ & ğ & & $\begin{array}{l}19 \\
22\end{array}$ \\
\hline E. Eorniferum & $\stackrel{t}{\mathrm{P}}$ & & & & & $\stackrel{0}{1}$ & $\stackrel{1}{1}$ & $\begin{array}{l}0 \\
5\end{array}$ & $\begin{array}{l}0 \\
5\end{array}$ & 12 \\
\hline S.tuberosum $3 p \cdot g r$. & $\stackrel{\mathrm{L}}{\mathrm{P}}$ & $\stackrel{0}{1}$ & & $\frac{0}{2}$ & & & $\stackrel{0}{1}$ & $\stackrel{0}{2}$ & $\stackrel{0}{3}$ & $\stackrel{0}{g}$ \\
\hline E. cargathicum & $\stackrel{L}{P}$ & & & & & & & & $\stackrel{0}{0}$ & $\stackrel{0}{8}$ \\
\hline c. pallipes & $\stackrel{L}{P}$ & & & & & & & & $\begin{array}{l}0 \\
6\end{array}$ & $\begin{array}{l}0 \\
6\end{array}$ \\
\hline P. ursinum & $\stackrel{t}{p}$ & $\frac{0}{5}$ & & & & & & & & $\begin{array}{l}0 \\
5\end{array}$ \\
\hline S. monticola & $\stackrel{\mathbf{L}}{\mathbf{P}}$ & $\frac{0}{2}$ & & $\stackrel{0}{i}$ & & & & & $\begin{array}{l}1 \\
0\end{array}$ & $\begin{array}{l}1 \\
3\end{array}$ \\
\hline C. tredecimata & $\stackrel{\mathrm{L}}{\mathrm{P}}$ & & & $\frac{2}{1}$ & & & & & & 2 \\
\hline Total & & 10 & 6 & 36 & 70 & 6 & 99 & 138 & 33 & 398 \\
\hline
\end{tabular}

flight period of $C$. tredecimata extended into September in 1983.

\subsection{Samples of larvae and pupae}

Hand picking of larvae and pupae in August 1986 revealed a total of 11 species of black-flies (Table III). Due to previous misidentification Eusimulium corniferum (Yankovsky) is hitherto known in Norway as E. bicorne Dorogostaiskii, Rubzov \& Vlasenko (Raastad 1979). Eusimulium carpathicum Knoz might prove to be the species that is reported from Norway under the name E. bellukovae Rubzov (Raastad \& Davies 1977). The occurence of the latter nominal species in Norway cannot be verified at present.

Hand picking of larvae and pupae in June-July 1988 revealed a total of 9 species of black-flies (Table IV). The dominant species at the outlet of the glacier fed Istjern in the middle-alpine zone was $P$. ursinum, while at the outlet of lake Gluptjern, which is also in the middle-alpine zone, C. trede- cimata was the dominant species. Other species at these sites were scarce. Prosimulium hirtipes (Fries) sp. group and Eusimulium cryophilum Rubzov were not recorded in the Malaise traps in 1983, but were collected as larvae/pupae in 1988.

The commonest species at Dovre in the sub-alpine and low-alpine zones in August seems to be Eusimulium crassum Rubzov. E. crassum far outnumbered the other species in the five bog streams (Table III), but $E$. vernum (Macquart) sp. group, $E$. aureum (Fries) sp. group and Simulium ornatum Meigen were also common. Scarce, but also present in the bog stream habitat were Cnephia pallipes (Fries) sp. group, E. corniferum, E. carpathicum, $S$. monticola Friederichs and $S$. tuberosum (Lundström) sp. group.

C. pallipes, E. crassum, E. aureum, E. corniferum, and $E$. carpathicum were only recorded from bog streams, while $P$. ursinum and $C$. tredecimata were restricted to torrential outlet stream habitats. 
Table IV. Numbers of black-fly larvae and pupae collected from five streams at Dovrefjell in June-July 1988

\begin{tabular}{|c|c|c|c|c|c|c|c|}
\hline & Loc.\# & 10 & 11 & 12 & 13 & 14 & Total \\
\hline P. ursinum & $\stackrel{\mathrm{L}}{\mathrm{p}}$ & & 6.7 & & $\begin{array}{l}6 \\
0\end{array}$ & & 73 \\
\hline P. hirtipes so.gr. & $\cdot \stackrel{\mathrm{L}}{\mathrm{P}}$ & & & $\stackrel{0}{i}$ & & & $\stackrel{0}{1}$ \\
\hline C. trederimata & $\stackrel{L}{\mathbf{P}}$ & $\begin{array}{l}11 \\
25\end{array}$ & $\$$ & & & & $\begin{array}{r}15 \\
25\end{array}$ \\
\hline E.s. vernum sp.gr. & $\stackrel{\mathbf{L}}{\mathbf{P}}$ & & & $\stackrel{0}{1}$ & & & $\stackrel{0}{1}$ \\
\hline E. Earpathirum & $\stackrel{L}{\mathrm{P}}$ & & & & 3 & $\stackrel{0}{1}$ & 3 \\
\hline E. eryophilum & $\stackrel{\mathrm{L}}{\mathrm{P}}$ & & & & & $\frac{0}{2}$ & $\frac{0}{2}$ \\
\hline E. corniferum & $\stackrel{L}{\mathbf{P}}$ & & & & $\stackrel{0}{2}$ & $\begin{array}{l}0 \\
4\end{array}$ & $\begin{array}{l}0 \\
6\end{array}$ \\
\hline s. ornatum sp.gr. & $\stackrel{t}{\mathrm{p}}$ & & & $\frac{0}{3}$ & & & $\stackrel{0}{3}$ \\
\hline S. tuberosum sp.gr & $r \cdot \frac{L}{p}$ & & & $\stackrel{0}{\mathbf{i}}$ & & & $\stackrel{0}{1}$ \\
\hline Total & & 36 & 71 & 6 & 12 & 7 & 132 \\
\hline
\end{tabular}

On average the species diversity was lower in the torrential outlet stream habitat than in the bog streams.

\section{Discussion}

This paper reports a total of 13 black-fly species from the Dovre mountains national park. Of these, two were Prosimulium spp., two Cnephia spp., five Eusimulium spp. and four Simulium spp. A complete list of species is of course difficult to obtain for several reasons, and it may be assumed that the real number of species can be higher. Some species will be naturally scarce and in low numbers because they are living in marginal habitats and thus are very difficult to sample. Some early flying species will also be scarce because we started collecting too late in the year. This primarily applies to those species that overwinter as larvae, i.e. $P$. hirtipes, $S$. orna$t u m, S$, monticola and to some extent $E$. vernum. On the other hand, there is no reason to believe that particular species have been overlooked in this survey but we would have expected at least one mammalophilic species to be generally abundant in the national park. Siebke (1877) reported Schoenbaueria pusilla (Fries) and Simulium reptans (L.) from
Dovre. Together with Simulium truncatum (Lundström) and $S$. corbis Twinn ( = rostratum Lundström sensu auct.) these are probably the species which are the greatest nuisance to man in Norway (Raastad 1974 b, 1981 and unpubl.). Though Sch. pusilla and $S$. reptans once seem to have been common in Scandinavia they are both rare today and would hardly be overlooked at Dovre. Siebke (1877), who put all black fly species in the genus Simulia, mentions that Prosimulium ferrugineum was absent from Dovre, and this is confirmed by us.

In contrast to the restricted abundance of typical mammal feeders at Dovre is the occurrence of the many bird-feeding Eusimulium species in the subalpine and low-alpine vegetation zone, i.e. $E$. vernum, E. cryophilum, E. corniferum, E. carpathicum and $E$. aureum. In addition, the black fly fauna of the middle-alpine and upper part of the lowalpine zones seems to be dominated by three species that are not blood-suckers : $P$. ursinum, $C$. tredecimata, and $E$. crassum. None of these flies much, but they tend to aggregate in the surroundings of their breeding place as they do not need to seek a host. $P$. ursinum was dominant at the outlet of the 
glacier fed Istjern $(1630 \mathrm{~m})$ and $C$. tredecimata dominated the samples from the outlets of Gluptjern and Stroplsjøen (1 452 and $1289 \mathrm{~m}$ respectively), which were the highest sites sampled. E. crassum dominated in the humus bog streams of the subalpine birch forest at $1040-1080 \mathrm{~m}$.

The occurrence of non-biters at Dovre is hardly surprising. Other studies have shown non-biters to predominate in arctic or high altitude areas (Downes 1965). The non-biting nature of $P$. ursinum, which is triploid and parthenogenetic (Davis 1954, Basrur \& Rothfels 1959) has been discussed by Carlsson (1962), who mentions that larvae of this species sometimes hatch from eggs ripened in the pupae and thus eliminate the adult phase. $P$. ursinum has a restricted distribution and is known frour Greenland, Iceland, Bear Island and Fennoscandia. It seems mostly to occur in glacier fed streams and Downes (1966) argues that $P$. ursinum is a truly arctic species. The present study supports this view in that we found it to be one of the dominant species in the high-alpine zone at Dovre.

C. tredecimata is well known from the Norwegian mountain group Jotunheimen, where the adult flies emerge in enormous numbers at the outlet of Lake Gjende in September (Olstad 1923, Carlsson 1962). This species is confined to the outlet habitat (Ulfstrand 1968, Raastad 1978, Carlsson et al. 1977), and it is distributed over most of boreoalpine Fennoscandia and into the Soviet Taiga (Rivosecchi et $a l$. 1975). The literature is confusing about the feeding habits of adult $C$. tredecimata. Rubzow (1959-64), followed by Carlsson (1962), classified C. iredecimata as a blood-sucking species. However, Rivosecchi et $a l$. (1975) found evidence of autogeny in a closely related species from Sardinia, and also mentions that Norwegian $C$. tredecimata are autogenous. Though we did not test the autogeny of $C$. tredecimata in the laboratory, captured females from Dovre had mature eggs in the abdomen, but empty and non-functional guts, adding to the evidence that C. tredecimata are autogenous in Norway.

Until recently $\boldsymbol{E}$. crassum was only known from the USSR but has now also been found in Fennocandia (Raastad \& Davies 1977, Raastad 1979). E. crassum was found in small streams draining bogs and mires in Rendalen (Raastad 1974), and in the Dovre mountains it seems to occur in any stream with a reasonable humus content.
Evidence that Eusimulium crassum is a nonbloodsucking species with reduced mandibles and lacinae was recently given by Davies et $a l$. (1977), who mention four other autogenous black-fly species with reduced female mouthparts in Norway : P. ursinum, P. macropygum (Lundström), C. lapponica (Enderlein) and E. baffinense (Twinn).

Autogeny linked with asexual reproduction is an adaptation that is advantageous at high altitudes and in the arctic. This adaptation is found in $P$, ursinum, while $C$. tredecimata and $E$. crassum reproduce sexually but seem to cope with the harsh climate through autogeny.

It is a striking feature that the three highest sites sampled (Istjern, Gluptjern and Stroplsjøen) were dominated either by $P$. ursinum or by $C$. tredecimata. One or the other of these species outnumbered other species completely or nearly so. Possibly the two species compete for the sames resources, but with significant differences in their reproductive strategies. Apparently $C$. tredecimata is confined to outlet habitats (Ulfstrand 1968, Carlsson et al. 1977). While several studies have documented that $P$. ursinum is restricted to cold and glacier fed streams (Davies 1954, Carlsson 1962, Raastad 1974), the present study shows that at high altitude $P$. ursinum is common and dominates at outlet habitats as well. At the lowest sites, Gluptjern and Stroplsjøen, sexual reproduction is an advantageous strategy in Simuliidae, while at the highest site, Istjern, parthenogenetic asexual reproduction has a selective advantage.

The climate is certainly an important factor in deciding which strategy is successful. When comparing it with the caddisfly fauna at the outlets of Istjern and Gluptjern, Solem 1985 a) found only $A p a-$ tania zonella Zetterstedt at Istjern, and this species also dominated the caddisfly community at Gluptjern. A. zonella reproduces mainly by parthenogenesis, only $1,5 \%$ males occurred at Dovre. This indicates that the sexual reproduction strategy in black-flies can cope more successfully with a harsh climate than can tho similar reproduction strategy in caddisflies.

\section{Acknowledgements}

The English of this paper has been revised by Mrs Alison Jane Coulthard and the French resume by Mrs Christiane Filion-Myklebust. 


\section{Literature cited}

Basrur (V.R.) \& Rothfels (K.H.). 1959. - Triploidy in natural populations of the black fly Cnephia mutata (Malloch). Can. J. Zool. $37: 571-589$.

Carisson (G.). 1962. - Studies on Scandinavian black flies (Fam. Simuliidae Latr.). Opusc. ent., Suppl. 21 : 1-280.

Carlsson (M.), Nilsson (L.M.), Svensson (B.), Ulfstrand (S.) \& Wotton (R.). 1977. - Lacustrine seston and other factors influencing the blackflies (Diptera : Simuliidae) inhabiting lake outlets in Swedish Lapland. Oikos $29: 229-238$.

Davies (D.M.), Gyorkos (H.) \& Raastad (J.E.). 1977. - Simuliidae (Diptera) of Rendalen, Norway. IV. Autogeny and anautogeny. Norw. $J$. Ent. $24: 19-23$.

Davies (L.). 1954. - Observations on Prosimulium ursinum Edw. at Holandsfjord, Norway. Oikos 5, 94-98.

Downes (J.A.). 1962. - What is an arctic insect ? Can. Ent. 94 : 143-162.

Downes (J.A.). 1964. - Arctic insects and their environment. Can. Ent. $94: 279-307$.

Downes (J.A.). 1965. - Adaptations of insects in the aretic. Ann. rev. Ent. $10: 257-274$.

Fjetlberg (A.). 1987, - Collembola from the Dovrefjell National Park, South Norway. Fauna norv. Ser. B. 34 : 73-74.

Greve (L.), Solem (J.O.) \& Bretten (S.). 1987 a. - Distribution, abundance and phenology of adult Neuropteroidea (Orders Planipennia, Raphidioptera and Megaloptera) and Mecoptera in the Dovrefjell mountains, South Norway. Founa norv. Ser. $B, 34: 57-62$.

Greve (L.), Solem (J.O.) \& Bretten (S.). 1987 b. - Bibionidae, Xylophagidae, Rhagionidae, Psilidae, Micropezidae, Clusiidae and Piophilidae (Diptera) from the Dovrefjell National Park, South Norway. Fauna norv. Ser. B, 34 : 75-79.

Hofsvang (T.), Solem (J.O.) \& Bretten (S.). 1987. - Distribution and seasonal abundance of adult Tipulidae (Diptera) in the Dovrefjell National Park, South Norway. Fauna norv. Ser. B, $34: 51-56$.

Mendl (H.), Solem (J.O.) \& Bretten (S.). 1987. - Distribution and seasonal abundance of adult Limoniidae (Insecta, Diptera, Nematocera) in the Dovrefjell National Park, South Norway. Fauna norv. Ser. B, $34: 63-72$.

Norhagen (R.). 1943. - Sikilsdalen og Norges fjellbeiter. Bergen Mus. Skr. 22 : $1-607$.

Nøst (T.). 1985. - Distribution of food habits of mayflies (Ephemeroptera) in streams in the Dovrefjell mountains, Central Norway. Fauna norv. Ser. B, 34 : 100-105.

Olsen (A.). 1987. - The thrips fauna near Kongsvoll in the Dovrefjell mountains (Sør-Trøndelag County, South Norway) ; distributions and habitat/host plant (Thys., Insecta). Fauna norv. Ser. B, $34: 80-91$.
Olstad (O.). 1925. - Gretvand i Gudbrandsdalen. Nyl Mag. Naturvit. $63: 1-202$

Raastad (J.E.). 1974 a. - Systematikk og populasjonsøkologi hos fennoskandiske knottarter (Diptera, Simuliidae), vi, 247 s. Universitetet i Oslo, Hovedoppgave.

Raastad (J.E.). 1974 b. - Outbreaks of blood-sucking black flies (Simuliidae) in Norway. Proc, third int. Congr. Parasitol. 2 : 918-919.

Raastad (J.E.) \& Davies (D.M.). 1977. - Black flies (Dipt., Simuliidae) new to Norway. Norw, J. Ent. $24: 33-34$.

Raastad (J.E.). 1979. - Fennoscandian blac-flies (Diptera, Simuliidae) ; annotated list of the species and their gross distribution. Rhizocrinus $11: 1-28$.

Raastad (J.E.). 1981 . - Blodsugende knott i Norge. Fauna 34 : $11-19$.

Rivosechi (L.), Raastad (J.E.) \& Contini (C.). 1975. - A new species of Simuliidae (Diptera) from Sardinia : Metacnephia nuragica, n. sp., and comparison to the related Fennoscandian M. tredecimata (Edwards). Riv. Parasit. $36: 215-222$.

Rubzov (I.A.) 1959-64. - 14 Simuliidae (Melusinidae). In E. Lindner (ed.) : Die Fliegen der Palaearktischen Region. Bd. 3 (4). E. Schweizerbart'sche Verlagsbuchhandlung, Stuttgart : $689 \mathrm{pp}$.

Rønning (O.I.). 1972. - Vegetasjonslaere. Universitetsforlaget, Oslo : $100 \mathrm{pp}$.

Siebke (H.). 1877. - Enumeratio Insectorum Norvegicorum. In J. Sparre Schneider (ed.) : Calalogum Dipterorum Continenrem. Fasc. IV. Christianiae (A.W. Broegger) : $225 \mathrm{pp}$.

Sjørs (H.). 1967. - Amphi-atlantic zonation; nemoral to arctic. pp. 109-125 in Löve, A. \& Löve, D. (Eds.) : North Attantic Biota and their History. Pergamon Press, Oxford.

Solem (J.O.). 1985 a. - Distribution ans seasonal abundance of adult Tipulidae (Diptera) in the Dovref jell National Park, South Norway. Fauna nory. Ser. B, 32 : 62-79.

Solem (J.O.). 1985 b. - Norwegian Apatania Kolenati (Trichoptera : Limnephilidae) ; identification of larvae and aspects of their biology in a high-altitude zone. Ent. scand. 16 : 161-174.

Solem (J.O.), Steinkjer (J.) \& Bretten (S.). 1987. - Distribution and seasonal abundance of adult Tipulidae (Diptera) in the Dovrefjell National Park, South Norway. Fauna norv. Ser. $B, 34: 45-50$.

Ulfstrand (S.). 1968. - Benthic animal communities in Lapland streams ; a field st udy with particular reference to Ephemeroptera, Plecoptera, Trichoptera and Diptera Simuliidae. Oikos, Suppl, $10: 1-120$.

Wood (D.M.) \& Davies (D.M.). 1966. - Some methods of rearing and collecting black flies (Diptera : Simuliidae). Proc. Ent. Soc. Ont. $96: 81-90$. 